\title{
How Option Markets Affect Price Discovery on the Spot Markets: A Survey of the Empirical Literature and Synthesis
}

\author{
Afef ANSI (Corresponding author) \\ IHEC-Carthage School of Management, Tunis University \\ The High Institute of Business Administration of Gafsa \\ oucine IBN GADDOUR Street, Sidi Ahmed ZARROUG \\ fsa 2112, Tunisia \\ Tel: 216- 93- 80- 58 -27 E-mail: afefansi@yahoo.fr \\ Olfa BEN OUDA \\ IHEC-Carthage School of Management, Tunis University \\ Tel: 216- 98- 64- 80-64Ｅ-mail: benoudaolfa@yahoo.fr
}

\begin{abstract}
The aim of this paper is to survey a wide range of empirical papers on option markets to address the extent to which option markets affect price discovery on the spot market. The theoretical prediction that informed traders should sometimes trade in the option market has been examined empirically by several authors. The existing empirical evidence for such a view, however, is mixed. One group of researchers support the hypothesis that information reflects in option market first and find a significant lead for the option market. Another group of researchers support the hypothesis that information reflects in stock markets first and trading activities in option markets are not significant. Since there is no consensus among the empirical studies on this issue, it leaves us with some open theoretical and empirical issues.
\end{abstract}

Keywords: Option market, Informed traders, Spot market, Price discovery

\section{Introduction}

Increasing trading activity in and, in fact, the very existence of organized stock option markets shows that many investors do in fact trade in the derivatives markets. This attest to the economic benefits that these financial contracts provide. In complete markets, option trading should convey no new information to market participants because options are derivative securities and are then redundant [Black and Scholes (1973) and Merton (1973)]. This is logical since the spot and the option markets should reflect simultaneously the arrival of information.

However, in the absence of market completeness, informed traders may prefer to trade options instead of the underlying stocks for a couple of reasons. First, authors such as Black (1975) ${ }^{1}$ and Mayhew, Sarin, and Shastri (1995), among others, argue that reduced transaction costs and increased financial leverage may induce informed traders to trade in the option market instead of the stock market, to which we must add the lack of short sales constraints in these markets. Second, Back (1993) and Cherian (1993) point out that investors that bet on volatility can only do so in the options market. Nevertheless, what might dissuade investors from engaging in the above practices is a possible preference to trade in the underlying asset market, which offers a higher level of liquidity than the options market.

To what extent is the informational role of options theoretically justified? To what extent has it been supported by empirical work? This topic has been the focus of much study. To our knowledge, neither the theoretical models nor the empirical studies ${ }^{2}$ provide a definitive answer about this. The purpose of the present article is to provide a comprehensive review especially of the empirical literature on this issue. There is considerable academic discussion relating to the dynamics of the interaction between stock and option markets (see Easley, O'Hara, and Srinivas, 1998 among others). However, conflicting results have been obtained.

Understanding where informed traders do trade also has important impacts on the industry, which will benefit both the 
academic and financial communities. The latter include investors who trade in both shares and derivatives, as well as those who are active in only one market. For instance, if the findings show that the option market contributes significantly to price discovery, this indicates that some information is first reflected in that market, and movements in these markets will be of interest to investors watching for signals about future price movements. Further, an understanding of where informed traders choose to trade and the factors influencing this choice, are relevant to market makers and regulators (for example, in helping to prevent illegal insider trades). For example, a knowledge of the 'informative-ness' of orders will aid option market makers in managing the risks from adverse selection. In addition, an analysis of the origin of information-based trading activity will be of relevance to both policy makers and exchange regulators.

In this paper we provide a comprehensive analysis of the empirical literature on the informational linkage between the option and stock markets. The evidence on market interrelationships, however, is inconclusive as to which of the two markets reflects new information earlier. This paper contributes to the literature in several ways. It is not, of course, the first one that provides a summary of previous empirical research in this field but to the best of our knowledge, this is the first paper to provide a more recent literature and a Schema that makes a synthesis of the literature in the light of both the approach used and the empirical results found.

In contrast to the abundance of empirical research, there are relatively few analytical models that examine the impact of option trading on stock and option prices. Before we present the empirical literature review, we like to address some theoretical framework issues first. The theoretical motivation for analyzing the effect of option trading on underlying asset prices comes from the growing literature on how to incorporate conditioning information in asset-pricing models ${ }^{3}$. This is the central focus of all information-based models, which differ in their modeling approach but coincide in incorporating information into stock prices as the result of informed and uninformed trading. Two major references in this vein are Glosten and Milgrom (1985) and Easley and O'Hara (1987).

The consideration of derivatives introduces a new market to the scene, thus enriching the existing literature, since it adds to the relationship involving trading, prices and private information a new type of asset that may incorporate further information and thereby affect the pre-existing relationships. Some studies that include derivatives in these relationships are: Grossman (1988), Back (1993), Biais and Hillion (1994), Brennan and Cao (1996), Easley, et al (1998) and John, et al (2003), among others.

The remainder of this article is organized as follows. Section2 describes the background of the literature. In section3, we review the empirical literature on the lead-lag relationship. In section4, we present the factors affecting market performance and review the empirical literature examining the information-share approach. In section5, we review the more recent empirical literature applying different approaches to different markets. Finally, section6 concludes the paper and discusses some avenues for further research on the interaction between option and cash markets.

\section{The background of the literature}

As soon as the emergence of the first option markets in the middle of $1970 \mathrm{~s}^{4}$, many authors have examined the microeconomic and macroeconomic effects induced by the introduction of new contracts. Since then, the availability of new high-frequency databases has served to deepen these studies. Two lanes were mainly borrowed. The first consists in studying the impact of the introduction of contracts on liquidity, return or volatility of the underlying asset.

The second group of empirical studies has focused on how the option markets affect the process of price adjustment and the dissemination of information. It consists, more specifically, in estimating the speed at which new information is reflected in the price, through lead-lag relations. It allows in particular, to analyze which of the two markets reflects new information earlier and to study which market will bear the orders of informed investors ${ }^{5}$.

Concerning the impact of options on the characteristics of the underlying asset, three effects have mainly been studied: the impact of option introduction on liquidity, on price dynamics, or even on the underlying asset volatility. In all cases, the idea is to compare the situation of two samples of stocks: one whose securities used as underlying assets of option contracts, the other not. It can be either of two different groups made up of stocks with similar characteristics observed on the same period (longitudinal study), or in a single group, observed before and after the introduction of option contracts (cross-sectional study) ${ }^{6}$. The broad conclusions that have been drawn from these studies are that options listing leads to a reduction in the volatility of stock returns, a reduction in stock bid-ask spreads, and an increase in the informativeness of stock prices?

The aim of the second area of research which will be the subject of the next sections is to study, continuously, the links between derivative and cash markets. Overall, these studies do not allow concluding that the options market incorporates new information more promptly. In other words, that it plays a leading role in the disclosure of information. 


\section{Lead-lag relationship: The survey of the empirical literature}

Why might informed traders prefer to trade in the option markets? As argued by Black $(1975)^{8}$, informed investors may be attracted by the high leverage achievable through options. A number of authors have developed "sequential-trade" models, where informed traders can trade in either the stock or option market (Biais and Hillion (1994), Easley, O'Hara, and Srinivas (1998) and John et al (2003), among others). These papers suggest that the amount of informed trading in option markets should be related to the depth or liquidity of both the stock and option markets, and the amount of leverage achievable with the option ${ }^{9}$. In short, informed traders should sometimes trade in the options market. This theoretical prediction has been examined empirically by several authors. The existing empirical evidence for such a view, however, is mixed. Table 1 provides a summary of previous empirical research in this field. Schema 1 makes a synthesis of the literature in the light of both the approach used and the empirical results found.

\subsection{Lead-lag relationship between stock prices and option prices}

\subsubsection{From closing prices to intraday data}

Manaster and Rendleman (1982) investigate this issue by using the observed option prices to calculate Black and Scholes implied stock prices. The implied stock prices are then compared with observed stock prices. Based on their examination of daily closing data on individual stock options from April 1973 to June 1976, Manaster and Rendleman (1982) conclude that the implied prices and then option prices contain information regarding equilibrium stock price that is not fully reflected in observed stock prices. They reject the hypothesis that implied stock prices provide no information regarding the future movements of observed stock prices. Furthermore, they report that it takes up to one day for stock prices to adjust. However, the use of closing price data seriously undermines the interpretation of their results. Closing option and stock transactions do not always take place at the same time ${ }^{10}$. Therefore, it is possible that additional information contained in closing option prices merely reflects more recent rather than better information.

Although the quality of data of Manaster and Rendleman (1982) is relatively poor, Bhattacharya (1987) confirms their trading strategy results by using intraday transaction data. In order to examine the intraday lead/lag relation between the markets, he uses observed bid/ask call prices to compute implied bid/ask stock prices, which are, in turn, compared to actual bid/ask stock prices to identify arbitrage opportunities. The stock is considered underpriced (overpriced) if the implied bid (ask) is higher (lower) than the actual ask (bid). Rather than simply testing for statistical relationships, Bhattacharya (1987) measures the profitability of trading strategies using a simulated trading strategy based on these arbitrage signals. Although he finds none of the intraday trading strategies generate significantly positive profits, he confirms the Manaster and Rendleman (1982) trading strategy results that option markets tend to lead stock markets by documenting statistically significant excess returns for overnight holding periods.

A critical aspect of the methodology employed in both Manaster and Rendleman (1982) and Bhattacharya (1987) papers is that it tests only whether option prices contain leading information relevant to the stock market, not whether the stock market might also lead the option market ${ }^{11}$. Anthony (1988) takes another approach by examining the interrelation between common stock and call option trading volume from January 1, 1982 to June 30, 1983. The study, using Granger causality tests via the conventional vector-autoregression (VAR), examine whether trading in the option market causes trading in the stock market (or vice versa). He concludes that "...trading in call options leads trading in the underlying shares with a one day lag". He finds weak evidence that option market volume leads stock market volume. However, his results are subject to the same caveats as Manaster and Rendleman (1982) due to the non simultaneity of the closing times for the two markets.

Stephan and Whaley (1990) examine intraday relations between price changes and trading volume of options and stocks for a sample of firms whose options were traded on the Chicago Board of Options Exchange (CBOE) during the first quarter of 1986. Their approach circumvents the two major problems of the previous studies. First, by using transaction-by-transaction data, they avoid the biases inherent in the non simultaneity of closing prices in the two markets. Second, the analysis focuses directly on the lead/lag relation between the intraday price changes in the stock and option markets rather than indirectly through simulating a trading strategy.

Breaking the data into five-minute intervals, they transform observed call price changes into implied stock price changes using a Roll-style American option formula, and then use multivariate time series regression analysis to estimate directly the lead/lag relations between the price changes in the stock and option markets ${ }^{12}$. Unlike the previous studies, they find evidence that price changes in the stock market lead the option market by as much as fifteen minutes, and stock trading volume leads option trading volume by slightly longer than that.

However, Chan, Chang and Johnson (1993) report that this result vanishes when quote midpoints are used, rather than transaction prices. They argue that the Stephan and Whaley (1990) result is biased due to infrequent trading, different price discreteness rules in the stock and option markets, and the fact that a one-tick change in the stock price corresponds to an option price change that is less than one tick. They conclude that neither market leads. Vijh (1990) and Srinivas (1993) examine this linkage issue indirectly by looking at how option prices move with option trades. Vijh 
(1990) concludes that the price effect of large option trades is small, therefore suggesting that option trades are not informative ${ }^{13}$. Srinivas (1993) argues that this is due to a bias in Vijh's sample selection and presents evidence that option trades are informative. Krinsky and Lee (1997) find that Stephan and Whaley's (1990) result seems to reverse around the time of earnings announcements, with options leading stocks in these periods, but like Chan, Chang and Johnson (1993), they find no significant lead-lag relationship in quote midpoints.

More recently, Diltz and Kim (1996) and O'Connor (1999) examine the lead-lag relationship between stocks and options quotes using an error correction model that recognizes that the observed stock price and the option-implied stock price are cointegrated. Diltz and Kim (1996) suggest, from daily data for eight firms negotiated on the CBOE in the first quarter of 1986 that the causality is bi- directional ${ }^{14}$. However, O'Connor (1999), using the TORQ database for 19 firms during November and December, 1990, finds that the stock market tend to lead the option market, and that the lead time is cross-sectionaly related to various measures of option liquidity and trading costs. Stucki and Wasserfallen (1994) find the same result. They conclude that the Swiss stock market lead the Swiss Options and Financial Futures Exchange (SOFFEX) by ten minutes on average.

\subsubsection{How to circumvent problems raised by using intraday data?}

All these empirical studies, among others of lead-lag relations between the option and stock markets compare option and stock transaction prices, quotes, or volume changes using fixed intervals. The use of intraday data is a priori more accurate ${ }^{15}$. Nevertheless, the use of intraday data also raises new problems since those data are more prone to infrequent trading (i.e. asynchronous prices) and to measurement error ${ }^{16}$. To our knowledge, three adaptations for asynchronous trading have been proposed. DeJong and Donders (1995) propose an econometric solution. They estimate the true returns taking into account the asynchronous and non-trading problems. Bruand and Gibson-Asner (1998) use a VAR model and a Granger's test to be free from the pricing model. They select only the contemporaneous trades on each market to cancel the asynchronous trading and filter the time series with a unit-root test.

Finucane (1999) employs a new methodology involving the construction of variable-length return intervals, for call options and the underlying stocks. The method is designed to detect leads that are shorter than five minutes, and accurately measure lead lengths. Allowing the length of the return intervals to vary with the frequency of market activity avoids potential biases created by the presence of intervals with no trading activity, and allows for the unambiguous identification of leads that previous studies classify as contemporaneous price changes. He constructs his data set in event time, and he defines price changes as changes in bid-ask quote midpoints. He models the option price change as a linear function of two lagging and leading stock price changes, and estimates the model using the Generalized Method of Moments. Examining data from November and December 1990 on ten firms, Finucane (1999) finds evidence that stock price changes lead option price changes, but also that option price changes lead stock price changes. To assess the length of the relationships, he increases the minimum of time between the quote changes he uses until the disappearance of any relationships. He concludes that stock prices lead option prices by no more than six minutes, and option prices lead stock prices by no more than three minutes.

\subsection{Lead-lag relationship between stock indices and stock index options}

While the aforementioned studies come to conflicting conclusions as to whether the stock market leads the option market, they consistently find no significant lead for the options market. This conclusion applies to the individual stock market not the index options market where the underlying is not a traded asset. Fleming, Ostdiek and Whaley (1996) examine the interactions between the S\&P500 index, options and futures contracts on this index. They conclude that the derivatives markets lead systematically the spot market, while the futures market precedes the options market, in particular due to a more important liquidity, and therefore to less high transaction costs on the former.

De Jong and Donders (1998) examine the Dutch market. As previously, the futures contracts lead both the options and the index by about 10 minutes. The relationship between the options market and the spot market is not unidirectional. Finally, Booth so and Tse (1999), examining the relationship between the German derivative markets and the DAX index, find cross linkages among the three markets. In particular, they conclude that the spot market lead the options market. In the case of French markets, Capelle-Blancard and Vandelanoite (2002), using Granger linear and non-linear causality tests between European options and the CAC40 index, find that the spot market leads the options market.

\subsection{The information in option volume for stock prices}

A number of authors, while providing indirect evidence of informed trading in option markets, take a slightly different approach. For example, Mayhew, Sarin, and shastri (1995) find evidence that informed traders migrate between stock and option markets in response to changes in the option margin requirement. Using trade and quote data, Easley, O'Hara and Srinivas (1998) test whether option market volume leads stock price changes ${ }^{17}$. Their analysis is based on 44 trading days, October and November 1990, on 50 firms. They use the technique of causality testing proposed by Granger (1969), and Granger and Newbold (1977) to investigate the relationship between option volume and stock price changes, if one market leads the other, and if so for how long ${ }^{18}$. They find strong evidence that options markets are a 
venue for information based trading, and that properly defined option market volumes associated with "positive news" and "negative news" have predictive power for stock price movements ${ }^{19}$.

On the other hand, Chan, Chung and Fong (2002), also using trade and quote data for 14 firms for the first quarter of 1995, calculate signed volume and quote-midpoint returns for five-minute intervals. In order to examine the dynamics of price movements and order flows for stocks and their options, they specify a vector autoregression of stock returns, call option returns, put option returns, stock signed volume, call option signed volume, and put option signed volume. They then estimate the model by performing a separate ordinary least squares regression for each of these variables on the lagged values of all six variables. They find that stock returns lead call and put returns by at least three lags (15 minutes), and option returns lead stock returns by only one lag (5 minutes). They also find that signed stock volume leads stock and option returns by one lag, but contrary to the results reported by Easley, O'Hara and Srinivas (1998), signed option volume does not lead stock returns.

There is also evidence that options volume contains before the announcement of important firm specific news. For example, Amin and Lee (1997) find that a greater proportion of long (or short) positions are initiated in the options market immediately before good (or bad) earnings news on the underlying stock. In a similar vein, Cao, Chen and Griffin (2005) examine the relative information content of stock and option volume prior to takeover announcements ${ }^{20}$. They document abnormal trading activity in option markets prior to takeover announcements, for a sample of 78 events between 1986 and 1994. In time-series regressions they find that during the benchmark period, lagged stock volume imbalances are more informative of next-day returns and that lagged call volume imbalances are not related to returns. However, in the pre-announcement period, option imbalances become significant predictors of next day stock returns. In addition, these authors test the performance of trading strategies based on moving-average trading-volume triggers. They find that strategies based on abnormal option volume tend to be profitable, while those based on abnormal stock volume do not, supporting the conclusion that option market plays an important role in information revelation.

Using daily records of CBOE trading volume for all CBOE listed options from January 1990 through December $2001^{21}$, Pan and Poteshman (2006) have two main goals. The first is to determine whether option volume is informative for future stock prices. The second is to provide evidence on key features of information-based theoretical models. They find that Long-short stock portfolio formed from a put-call volume ratio get 40 basis points the next day and 100 basis points over the next week with very large t-statistics. Contrarily to Cao, Chen and Griffin (2005) and Chan, Chung and Fong (2002) who find that during "normal" times, stock volume not option volume predicts underlying stock returns, they produce strong evidence that option volume contains information about the future movements of underlying stock price. In addition they find that: (a) option volume is more predictive on stocks with higher concentrations of informed investors, (b) the volume of more levered options contains more information about future stock prices, and (c) option volume of full-service customers is most informative while there is no information in option volume of firm proprietary traders.

\section{Factors affecting market performance and information-share approach}

An emergent stream of the literature has delved into the microstructure of options markets in order to more closely understand the relation between information transmission in the two markets, leverage, and liquidity-related variables like spreads and volume. For example, Lee and Yi (2001) test to see if the greater leverage and lower trading costs make options more attractive to informed traders or if the relative lack of anonymity in options markets discourages large investors from trading options. Using a sample of relatively active stocks and their options, the authors find that the adverse selection component of the bid-ask spread decreases with option delta, implying that options with greater financial leverage attract more informed investors. Anand and Chakravarty (2003) have also found that in option markets, "stealth trading" (the propensity of informed traders to fragment trades into certain size classes) is a function of leverage and the underlying liquidity of the option contract.

The literature also indicates that moneyness affects informed traders' choice among different options. In a significant departure from a conventional analysis of the options markets, de Jong, Koedijk, and Schnitzlein (2001) use an experimental approach to examine the implications of asymmetric information for informational linkages between a stock and its traded call option. Their main finding is that an insider trades aggressively in both the option and the stock with most trades directed to the asset that affords the most profitable trading opportunity. Thus, they suggest informed traders use in-the-money (ITM) options to increase their trading profits because ITM are more sensitive to underlying equity price changes than other options. They also find that trades in the stock market imply quote revisions in the options market and vice versa. Hence, price discovery takes place in both markets.

Kaul, Nimalendran, and Zhang (2004) examine the relation between adverse selection in the underlying stock and spreads on options of different strike prices. Their main finding is that adverse selection costs are highest for at-the-money or slightly out-of-the-money options. The authors argue that this result is consistent with the trade-off between high leverage and transaction costs. Chen, Lung, and Tay (2005), using daily data of all the firms included in 
the S\&P500 index and their corresponding options negotiated on the CBOE in a period of approximately 7 years beginning on November 1st of 1995 and ending on December 31st of 2002, analyze the informational role of stocks and options across different option moneyness for firms with different degrees of information asymmetry ${ }^{22}$. They argue that informed traders, in deciding where to place their trades, are not entirely indifferent to option moneyness, degree of information asymmetry, and option liquidity. They discover feedback relations between trades in out-of-the money options and the underlying stocks. Moreover, they conclude that some informed traders are probably attracted to these options because of their higher liquidity, lower premiums, and higher delta-to-premium ratios.

Another strand of literature provides direct evidence of price discovery in the option market. The authors consider that lead-lag analysis tends to lump together permanent price changes, which represent new information entering the market, and transitory changes, which may result from mispricing or temporary order imbalances. They argue that if we are interested in knowing where informed trading occurs, we should focus on only the permanent component. To the best of our knowledge, Chakravarty, Gulen and Mayhew (2004) is the first paper to measure directly the percentage of price discovery across the stock and option markets, and to provide direct evidence of price discovery in the option market. Moreover, the authors investigate whether the relative rate of price discovery in the two markets is a function of firm characteristics that can be identified in a cross-sectional analysis.

To accomplish these objectives, Chakravarty, Gulen and Mayhew (2004) use a modification of Hasbrouck's (1995) "information share" approach ${ }^{23}$. Their results are consistent with theoretical arguments that informed investors trade in both stock and option markets, suggesting an important informational role for options. Indeed, based on five years of stock and options data for 60 firms, they estimate the option market's contribution to price discovery to be about 17 percent on average. Option market price discovery is related to trading volume and spreads in both markets, and stock volatility. Price discovery across option strike prices is related to leverage, trading volume, and spreads.

\section{More recent literature: different approaches to different markets}

In order to more closely investigate price discovery in options markets, the more recent studies apply a wide range of approaches. Richard, Yusif, and Liuren (2006) apply a portfolio approach to analyze price discovery in the United States stock and stock options. The authors consider that option prices vary with not only the underlying asset price, but also volatilities and higher moments. Hence, they use a portfolio of options to seclude the value change of the portfolio from the impact of volatility and higher moments. They find that price discovery on the directional movement of the stock price mainly occurs in the stock market. However, the options market becomes more informative during periods of significant options trading activities. Furthermore, Yusif and Liuren (2008) study price discovery in the United States stock options market. They describe the International Securities Exchange ${ }^{24}$ and present a comparison of the different exchanges' market-making systems along several dimensions, including the size of the typical bid-ask spread, how much a trade in each market contributes to a general updating of prices across the whole market, and how frequently trades are executed inside the quoted bid-ask spread ${ }^{25}$. Their results indicate that the electronic marketplace performs very well relative to the more traditional trading floors on all of these dimensions.

On the other hand, a number of authors study price discovery in Asian option markets. For example, by applying the method of open interest and volume-based predictors (Bhyan and Yan, 2002), Kedar and Mishra (2007) study the informational role of the options market in predicting the future price index in the underlying cash market in India. To explore the above relationship, daily data for both price as well as non-price variables, for two different sub-periods have been employed. Their findings confirm that the open-interest-based predictors- for both the periods-are found to be significant in predicting the future price in the underlying cash market. Nevertheless, during the recent sub-period, the trading volume shows some more impact when compared to open interest in the matter of price prediction in the cash market.

In the case of Korea, Hee, Jangkoo, and Doojin (2008) examine if informed trading is present in the index option market by analyzing the KOSPI $200^{26}$ options, the most actively traded derivative product in the world. The authors utilize the spread decomposition model developed by Madhavan, Richardson, and Roomans (1997) and then use the adverse-selection cost component of the spread estimated by the model as a proxy for the degree of informed trading ${ }^{27}$. They find that adverse-selection costs constitute a nontrivial portion of the transaction costs in index options trading. Approximately one-third of the spread can be accounted for by information asymmetry costs. Moreover, their regression analysis shows that option-related variables are significantly associated with estimated information asymmetry costs, even when controlling for proxies for informed trading in the index futures market.

Usually in the case of emerging markets, Wen-Liang, Chin-shen, and Shu-fang (2008) investigate the relative rate of price discovery in Taiwan between index futures and index options, proposing a put-call parity (PCP) approach to recover the spot index embedded in the options premiums ${ }^{28}$. Consistent with the trading-cost hypothesis, a dominant tendency is found for futures and a subordinate but non-trivial price discovery from options. More recently, Chang, Hseih, and Lai (2009) investigate the information content of options trading using a unique dataset to examine the predictive power of the put and call positions of different types of traders in the Taiwan option market. They find that 
options volume, as a whole, carries no information on Taiwan spot index changes. On the other hand, however, there is strong evidence to show that the trading in which institutional investors do engage has significant predictive power on the underlying asset returns.

\section{Conclusions}

In summary, there is no consensus among the empirical studies on the direction of information flow between the stock and option markets. Likewise, it is not clear where the informed traders choose to place their trades. However, we can make a synthesis of the literature in the light of both the approach used and the empirical results found. Indeed, several authors have provided indirect evidence consistent with the theoretical prediction that informed traders should sometimes trade in the option market (see, for example, Easley, O'Hara, and Srinivas (1998), Cao, Chen, and Griffin (2000), and Pan and Poteshman (2003)).

Given this corroborative evidence that informed traders use option markets, there is surprisingly little direct evidence that new information is reflected in option prices before stock prices (see Manaster and Rendleman (1982), Stephan and Whaley (1990), Vijh (1990), Chan, Chung, and Johnson (1993), Finucane (1999), and Chan, Chung, and Fong (2002)). The authors focus on which market leads (or lags) in terms of information arrival, through Granger lead-lag regressions and similar techniques.

While these studies come to conflicting conclusions as to whether the stock market leads the option market, they consistently find no significant lead for the options market. This conclusion applies to the individual stock market not the index options market where the underlying is not a traded asset (see for example, Fleming, Ostdiek and Whaley (1996)).

In order to circumvent the problem diagnosed in the lead-lag analysis that it tends to lump together permanent price changes and transitory changes, Chakravart, Gulen and Mayhew (2004) among others, provide direct evidence of price discovery in the option market. They find that options have an important informational role. In addition, they conclude that the relative rate of price discovery in the two markets is a function of firm characteristics. More recently, empirical studies examine if informed trading is present in some emerging option markets by applying mixed approaches.

The most important implication of the above literature survey is that it leaves us with some open theoretical and empirical issues. First, it raises doubts on the validity of most contingent claims pricing models which value options with a dynamic replicating strategy. From a conceptual perspective, it is clear that derivatives can no longer be treated as redundant securities. Second, on one hand, recent empirical evidence may help to determine whether there are further factors, such as firm or news characteristics, that might help to explain the complex relationships between informed trading volume, news, option prices and stock prices. Factors that might drive an informed trader to choose one market over another are liquidity, leverage, and transaction costs, and the type of market mechanism.

On the other hand, the majority of research focuses on directional information and on mature options markets such as the CBOE. In future research it would be interesting to explore information about the future volatility of underlying stocks and to understand information flow and price discovery in the emerging options market for two reasons. First, the typical emerging market usually has different trading regulations from mature markets. It would be informative to examine whether the regulations in a particular emerging market encourage or discourage informed trading activities in options market. Second, an emerging market is less efficient than a mature market, and insider trading regulations are lax. Hence, all else equal, trading in an emerging market provides more profitable opportunities for informed traders.

\section{References}

Amin, K., \& Lee,C. (1997). Option Trading and Earnings News Dissemination. working paper, University of Michigan. Anthony, J. (1988). The interrelation of stock and options market trading-volume data. Journal of Finance, 43, 949-964. Back, K. (1993). Asymmetric information and options. Review of Financial Studies, 6, 435-472.

Bessembinder, H., Chan.K., \& Seguin. P. (1996). An empirical examination of information, differences of opinion, and trading activity. Journal of Financial Economics, 40, 105-134.

Bhattacharya, M. (1987). Price changes of related securities: The case of call options and stocks. Journal of Financial and quantitative Analysis 22, 1-15.

Bhuyan, R. (2002). Information, alternative markets, and security price processes: A survey of literature. Working Paper.

Bhuyan, R., \& Yan, Y. (2002). Informational role of open interests and volumes: Evidence from option markets. Paper presented at Twelfth Annual Asia-Pacific Futures Research Symposium held in Bangkok, Dec. 3-4, 2001.

Biais, B., \& Hillion, P. (1994). Insider and Liquidity trading in stock and options markets. Review of Financial Studies, $74,743-780$. 
Black, F., \& Scholes, M. (1973). The pricing of options and corporate liabilities. Journal of Political Economy, 637-655.

Black, F. (1975). Fact and fantasy in use of options. Financial Analysts Journal, 31, 36-41.

Blasco, N., Corredor, P., \& Santamaria, R. (2006). Does informed trading occur in the options market? Some revealing clues. working paper, University of Zaragoza.

Booth G.G., So, R.W., \& Tse, Y. (1999). Price discovery in the German equity index derivative markets. Journal of Futures Markets, 19(6). 619-643.

Brennan, M., \& Cao, H. (1996). Information, trade, and derivative securities. Review of Financial Studies, 9, 163-208.

Brennan, M., \& Subrahmanyam, A. (1995). Investment analysis and price formation in securities markets. Journal of Financial Economics, 38, 361-381.

Bruand, M. \& Gisbon-Asner, R. (1998). The effects of newly listed derivatives in a thin stock market. Review of derivatives Research, 2 (1), 59-86.

Cao, C., Chen, Z. \& M. Griffin. (2005). The informational content of option volume prior to takeovers. Journal of Business, 78, 1073-1109.

Capelle-Blancard, G. (2001). Les marchés à terme d'options : organisation, efficience, évaluation des contrats et comportements des agents. Thèse de doctorat, Université Paris I Panthéon-Sorbonne.

Capelle-Blancard, G., \& Vandelanoite, S. (2002). Relations intrajournalières entre l'indice CAC40 et les options sur indice : quel est le marché préféré des investisseurs informés?. Annales d'économie et de Statistique, №66, 2002.

Chakravarty, S., Gulen, H., \& Mayhew, S. (2004). Informed Trading in Stock and Option Markets. Journal of Finance, 59 (3), 1235-1257.

Chan, K., Chung, P., \& Fong, W. M. (2002). The informational role of stock and option volume. Review of Financial Studies, 15, 1049-1075.

Chan, K., Chung, P., \& Johnson, H. (1993). Why option prices lag stock prices: A trading-based explanation. Journal of Finance, 48, 1957-1967.

Chan, K., Chung, P. \& Johnson, H. (1995). The intraday behaviour of bid-ask spreads for NYSE stocks and CBOE options. Journal of Financial and Quantitative Analysis, 30, 329-346.

Chan, K. C., Chang, Y., \& Lung, P.P. (2009). Informed trading under different market conditions and moneyness: Evidence from TXO options. Pacific-Basin Finance Journal, 17(2), 189-208.

Chang, C.C., Hsei, P.F., \& Lai, H.N. (2009). Do informed option investors predict stock returns? Evidence from the Taiwan stock exchange. Journal of Banking \& Finance, 33(4), 757-764.

Chen, C.R., Lung, P.P., \& Tay, N.S.P. (2005). Information flow between the stock and option markets: Where do informed traders trade. Review of Financial Economics, 14, 1-23.

Cherian, J. (1993). Option pricing, self-fulfilling prophecies, implied volatilities and strategic interaction. Unpublished Ph.D. dissertation, Cornell University.

Conrad, J. (1989). The price effect of option introduction. Journal of Finance, 44(2), 487-498.

Damodaran, A., \& Joseph, L. (1991). The effects of option listing on the underlying stocks' return process. Journal of Banking and Finance, 15, 647-664.

De Jong, C., Koedijk, K.C.G., \& Schnitzlein, C.R. (2001). Stock market quality in the presence of a traded option. working paper, Erasmus University.

De Jong, F., \& Donders, M. (1998). Intraday lead-lag relationships between the futures, options and Stock Markets. European Finance Review, 337-359, 1(3).

Diltz, J., \& Kim, S. (1996). The relationship between stock and option price changes.The Financial Review, 31,499-519.

Easley, D., \& O’Hara, M. (1987). Price, trade size and information in securities markets. Journal of Financial Economics, 19, 69-90.

Easley, D., O’Hara, M., \& Srinivas. P. (1998). Option volume and stock prices: Evidence on where informed traders trade. Journal of Finance, 53, 431-465.

Fedenia, M., \& Grammatikos, T. (1992). Options trading and the bid-ask spread of underlying stocks. Journal of Business, 65(3), 335-351. 
Franke, G., Stapleton, R., \& Subrahmanyam, M. (1998). Who buys and who sells options: The role of options in an economy with background risk. Journal of Economic Theory, 82, 89-109.

Figlewski, S., \& Webb, G. (1993). Options, short sales, and market completeness. Journal of finance, 48, 89-109.

Finucane, T.J. (1999). A new measure of the direction and timing of information flow between markets. Journal of Financial Markets, 2(2), 135-151.

Fleming, J., Ostdiek B., \& Whaley, R. E. (1996). Trading costs and the relative rates of price discovery in the stock, futures, and option markets. Journal of Futures Markets, 16, 353-387.

Glosten, L.R., \& Milgrom, P.R. (1985). Bid, ask and transaction prices in a specialist market with heterogeneously informed traders. Journal of Financial Economics, 14, 71-100.

Granger, C. (1969). Investigating causal relations by econometric models and cross-spectral methods. Econometrica, 37(3), p. 424-438.

Granger, Clive, W. J., \& Peter, N. (1977). Forecasting economic time series. Academic Press, New York.

Grossman, S. (1988). An analysis of the implications for stock and future price volatility of program trading and dynamic hedging strategies. Journal of Business, 61, 275-298.

Hasbrouck, J. (1995). One security, many markets: Determining the location of price discovery. Journal of Finance, 50, 1175-1199.

Hee.J.A., Jangkoo, K., \& Doojin.R. (2008). Informed trading in the index option market: The case of KOSPI 200 options. Journal of Futures Markets, 28(12), 1118-1146.

Ho, T., \& Stoll, H. (1983). The dynamics of dealer markets under competition. Journal of Finance, 83, $1053-1074$.

Jennings, R., \& Starks, L. (1986). Earnings announcements, stock price adjustment, and the existence of option markets .Journal of Finance, 41(1), 107-125.

John, K., Koticha, A., \& Subrahmanyam, M. (2000). The micro-structure of options markets: informed trading, liquidity, volatility and efficiency. Working paper, New York University.

John, K., Koticha, A., \& Subrahmanyam, M. (2003). Margin rules, informed trading in derivatives and price dynamics. Working paper, New York University.

Jones, C., Kaul, G., \& Lipson, M. (1993). Information, trading, and volatility. Journal of Financial Economics, 36, 127-154.

Kaul, G., Nimalendran, M., \& Zhang, D. (2004). Informed trading and option spreads. Working paper, University of Michigan.

Kedar, N.M., \& Mishra, R.K. (2007). Informational role of non-price variables: An empirical study of the Indian options market. The Icfai Journal of Applied Finance, 13(2), 32-45.

Kraus, A., \& Smith, M. (1996). Heterogeneous beliefs and the effect of replicatable options on asset prices. Review of Financial Studies, 9, 723-756.

Krinsky, I., \& Lee, J. (1997). Quarterly earnings announcements and the lead/lag relationship between the stock and option markets. Working paper, McMaster University.

Kyle, A. (1985). Continuous auctions and insider trading. Econometrica, 53, 1315-1335.

Jason, L., \& Cheong, H.Y. (2001). Trade size and information-motivated trading in the options and stock markets. Journal of Financial and Quantitative Analysis, 36, 485-501.

Jun, L., \& Jun, P. (2003). Dynamic derivative strategies. Journal of Financial Economics,

forthcoming.

Madhavan, A., Richardson, M., \& Roomans, M. (1997). Why do security prices change? A transaction-level analysis of NYSE stocks. Review of Financial Studies, 10, 1035-1064.

Manaster, S., \& Rendleman, R. (1982). Option prices as predictors of equilibrium stock prices. Journal of Finance, 37 , 1043-1057.

Mannaï, S. (1995). De la microstructure en général et de la liquidité en particulier: théories et études empiriques sur le Monep. Economica.

Mayhew, S., Sarin, A. \& Shastri, K. (1995). The allocation of informed trading across related markets: an analysis of the impact of changes in equity-option margin requirements. Journal of Finance, 505, 1635-1653.

Mayhew, S. (2000). The impact of Derivatives on Cash Markets: What Have We Learned?. Working Paper. 
Merton, R.C. (1973). The Relationship between Put and Call option Prices: Comment. Journal of Finance, 31, 369-381.

Nandi, S. (1994). Asymmetric information about volatility and options markets: Theory and evidence. Working paper, Washington University.

Neal, R. (1987). Potential and actual competition in equity options. Journal of Finance, 42, 511-532.

O'connor M. (1999). The cross-sectional relationship between trading costs and lead/lag effects in stock and option markets. Financial Review, 34, 95-118.

Pan, J., \& Poteshman, A. (2006). The information in option volume for stock Prices. Review of Financial Studies, 19(3), 871-908.

Richard, H., Yusif, S., \& Liuren, W. (2006). Price discovery in the U.S. stock options markets: A portfolio approach. Review of Derivatives Research, 9(1), 37-65.

Ranaldo, A. (2000). Intraday trading activity on financial markets: the Swiss evidence. Thesis, University of Fribourg.

Ross, S. A. (1976). Options and efficiency. Quarterly Journal of Economica, 90(1), 75-89.

Sims. (1972). Money, income and causality. American Economic Review, 62, 540-552.

Skinner, D.J. (1989). Options markets and stock return volatility, Journal of Financial Economics, 23, 61-78.

Srinivas, P. S. (1993). Trade size and the information content of option trades. Working paper, Cornell University.

Stephan, J, \& Whaley, R. (1990). Intraday price change and trading volume relations in the stock and stock option markets. Journal of Finance, 45, 191-220.

Stoll, H. \& Whaley, R. (1987). Expiration day effects of index options and futures," Financial Analysts Journal, 43, 16-28.

Stucki, T. \& Wasserfallen, W. (1994). Stock and option markets: the Swiss evidence. Journal of Banking and Finance, 18, 881-893.

Vandelanoite, S. (2002). Les modalités de transaction et d'incorporation de l'information sur les marchés financiers. Thèse de doctorat, Université Paris I Panthéon-Sorbonne.

Vijh, A. (1988). Potential biases from using only trade prices of related securities on different exchanges. Journal of Finance, 43, 1049-1055.

Vijh, A. (1990). Liquidity of the CBOE equity options. Journal of Finance, 45, 1157-1179.

Wen-Liang, G.H., Chin-Shen, L., \& Shu-Fang, Y. (2008). Price discovery in the options markets: An application of put-call parity. Journal of Futures Markets, 28(4), 354-375.

Yusif, E.S., Liuren, W. Winter. (2008). Price discovery in the U.S. stock options market. The Journal of Trading, Winter .

\section{Notes}

Note 1. "Since an investor can usually get more action from a given investment in options than he can by investing directly in the underlying stock, he may choose to deal in options when he feels he has an especially important piece of information" ( Black[1, p. 61]).

Note2. Empirical studies contribute to the understanding of why options are relevant in actual markets, by providing the unambiguous evidence that stock option trading contributes to price discovery in the underlying stock market.

Note 3. Most derivative pricing models assume complete markets where derivatives are redundant securities and hence not traded in equilibrium. But when traders with private information about the underlying stock can choose to trade the stock or the option, then options prices and trades contain valuable information and are no longer redundant.

Note 4. Since Ross (1976) first suggested that option introductions impact upon the value of the underlying asset, much research has focused on examining the validity of this hypothesis both through theoretical and empirical analysis.

Note 5. Note that if the first type of approach deals with comparative static, the second refers rather to a continuous analysis.

Note 6. The results of these studies should however, be considered with caution. Indeed, it is difficult to distinguish the effects caused directly by the existence of options, from those resulting from the events that have led to the introduction of these contracts.

Note 7. For evidence on the reduction in volatility, see Conrad (1989) and Skinner (1989); on the reduction in bid-ask spreads, see Damodaran and Lim (1991) and Fedenia and Grammatikos (1992); and on improved efficiency, see Damodaran and Lim(1991) and Jennings and Starks (1986)... 
Note 8. This idea is well explained in section 1.

Note 9. In addition, Capelle-Blancard (2001) presents a model in which some investors are privately informed about the stock value and others are privately informed about volatility. His results suggest that when there is greater uncertainty, there is likely to be more price discovery in the stock market and less in the option market.

Note 10. The option market closes at 3:10 PM (CST), ten minutes after the close of the stock market.

Note 11. Bhattacharya recognizes this problem but does not perform the simulations in the reverse way. Although he shows that option price changes have some predictive power, his results do not preclude the possibility that the stock price changes predict option price changes.

Note 12. Stephan and Whaley (1990) are the first to use both an intraday interval (5minutes) and a bi-directional test. Since the relation can be bi-directional (each market can lead the other and they can interact), it is preferable to use a causality test in the Granger's (1969) and Simms' (1972) meaning.

Note 13. Vijh (1990) argues further that Manaster and Rendleman (1982)'s methodology suffers from the bid-ask bias as well as the nonsynchroneity. He concludes that not accounting for the bid-ask bounce and the nonsynchroneity between stock and option prices in an ex post study can give the impression that the option prices lead the stock prices even when the tow are in equilibrium.

Note 14. They find evidence both for the stock market leading the option market and the option market leading the stock market.

Note 15. The last option trade or quote occurring in a particular interval is used as the representative price for that interval, and if no trade or quote is registered during a particular interval, transactions from previous intervals are typically applied to the empty intervals.

Note16. Measurement error caused by missing observations will affect the consistency and efficiency of coefficient estimates.

Note 17. They investigate the informational role of transactions volume in options markets.

Note 18. Dividing the trading day into five-minute intervals, they regress stock price changes on lagged option volume, and vice versa.

Note 19. Signed volume is calculated by first classifying trades as buyer or seller-initiated according to their location within the prevailing bid-ask spread, then lumping long call volume together with short put volume (volumes associated with "positive news"), and short call volume with long put volume (volumes associated with "negative news").

Note 20. The authors consider that takeover announcements are ideal events for studying information discovery in the security price formation process.

Note 21. A unique feature of their dataset is that the daily trading volume for each option is broken down into 16 categories defined by 4 trade types (open buy, open sell, close buy, and close sell) and 4 investor classes (firm proprietary traders, public customers of discount brokers, public customers of full-service brokers, and other public customers).

Note 22. Unlike some previous studies that find information to flow unilaterally from equity to options markets, they control for the above factors.

Note 23. The information-share approach measures the contribution of the innovation in the price process in one market (say the option market) to the total variance of the innovation in the permanent component of the price vector spanning both (stock and option) markets.

Note 24. In 2000, the International Securities Exchange (ISE) was launched, with an entirely different all-electronic trading arrangement. The ISE model has proven highly successful, making the exchange the most active market for individual stock options within only a few years.

Note 25. Meaning that the quoted spread did not fully reflect the best prices available at that exchange.

Note 26. The KOSPI 200 Index is the Korea Composite Stock Price Index. It is a capitalization-weighted index of 200 Korean stocks which make up 93\% of the total market value of the Korea Stock Exchange. The index was developed with a base value of 100 as of January 3, 1990.

Note 27. Their approach is similar to that applied by Kaul, Nimalendran, and Zhang (2004).

Note 28. The PCP approach offers the benefits of reducing model risk and alleviating the burden of volatility estimation. 
Table 1. Summary of empiricul reseurch in the links between option and cush markets

\begin{tabular}{|c|c|c|c|c|}
\hline Authors & Markets, Products and period & Data & Methodology & Results and criticisms \\
\hline Manaster-Rendlemun (1982) & $\begin{array}{c}\text { CBOE } \\
\text { Stock options } \\
\text { From } 04 / 73 \text { to } 06 / 76\end{array}$ & Deily closing prices & Simulated trading strutegy & $\begin{array}{l}\text { Options lead by one day } \\
\text { Biased results due to difference } \\
\text { in closing times }\end{array}$ \\
\hline Bhattacharyu (1987) & $\begin{array}{c}\text { CBOE } \\
\text { Stock options } \\
\text { From } 06 / 73 \text { to } 08 / 78\end{array}$ & Intraday transuctions & Simulated trading strutegy & $\begin{array}{l}\text { Options lend stocks by one day } \\
\text { Corroborative result with } \\
\text { M\&R(1982) }\end{array}$ \\
\hline Anthouy (1988) & $\begin{array}{c}\text { CBOE } \\
\text { Stock options } \\
\text { From } 01 / 82 \text { to } 06183\end{array}$ & Deily closing volumes & $\begin{array}{c}\text { ARIMA } \\
\text { Linear causality }\end{array}$ & $\begin{array}{l}\text { Options market lead stock } \\
\text { market by one day }\end{array}$ \\
\hline Stephim-Wbaley (1990) & $\begin{array}{c}\text { CBOE } \\
\text { Stock options } \\
\text { From } 01 / 86 \text { to 03/86 }\end{array}$ & Intraday transuctions & Multivariute unalysis & $\begin{array}{l}\text { Stock market lend the options } \\
\text { murket by as much as } 15 \\
\text { minutes }\end{array}$ \\
\hline Chan-Chung.Jotnson (1993) & $\begin{array}{c}\text { CBOE } \\
\text { Stock options } \\
\text { From 01/86 to 03/86 }\end{array}$ & Iniraday quotes & Linear causality & $\begin{array}{l}\text { The lead of S\&W (1990) } \\
\text { disuppears with quotes }\end{array}$ \\
\hline Stucki-Wusserfallen (1994) & $\begin{array}{c}\text { SOFFEX } \\
\text { Stock options } \\
\text { From } 01 / 89 \text { to } 12289\end{array}$ & Intraday transuctions & Linear causality & Cush murket lead by 10 minutes \\
\hline Diltz:Kim (1996) & $\begin{array}{c}\text { CBOE } \\
\text { Stock options } \\
\text { From } 01 / 86 \text { to } 03 / 86\end{array}$ & Duily quotes & Error Correction Model & Bidirextional causality \\
\hline$\sigma^{\prime}$ Connor $(19 y 9)$ & $\begin{array}{c}\text { CBOE } \\
\text { Stock options } \\
\text { From } 11 / 90 \text { to } 12 / 90\end{array}$ & Iniraday quotes & Error Cortection Model & $\begin{array}{c}\text { Stock market lend the options } \\
\text { market }\end{array}$ \\
\hline $\begin{array}{l}\text { Fleming-Ostdick-Whaley } \\
\qquad \text { (1996) }\end{array}$ & $\begin{array}{c}\text { CBOE } \\
\text { Index options }\end{array}$ & Iniraday quotes & Linear causality & $\begin{array}{l}\text { Option market lead the cash } \\
\text { market }\end{array}$ \\
\hline
\end{tabular}


$03 / 91$

\begin{tabular}{|c|c|c|c|c|}
\hline Delong-Donders (1998) & $\begin{array}{c}\text { AEX } \\
\text { Index options } \\
01 / 92 \text { to } 07 / 92.011 / 93 \text { to } 06093\end{array}$ & Initraday quotes & Cointegration tests-MCE & $\begin{array}{l}\text { Symmetricul relutionship of } \\
\text { index und options }\end{array}$ \\
\hline Bruand-(jibson Asner (1998) & $\begin{array}{c}\text { SOFFEX } \\
\text { Stock options } \\
\text { From } 01 / 89 \text { to } 12 / 89\end{array}$ & $\begin{array}{l}\text { Simultuneous intraday } \\
\text { transuctions }\end{array}$ & Test VAR und Granger & $\begin{array}{l}\text { Results unstable acoording to the } \\
\text { features of options and to the } \\
\text { underlying }\end{array}$ \\
\hline Finueune (1999) & $\begin{array}{c}\text { CBOE } \\
\text { Stock options } \\
\text { From 11/90 to 12/90 }\end{array}$ & $\begin{array}{l}\text { Intraday quotes } \\
\text { Every quote change is } \\
\text { registered to culculate } \\
\text { real time retumls }\end{array}$ & Linear cuusality by (GMM & $\begin{array}{l}\text { Lead of the cush market } \\
\text { The minimum is a few seconds } \\
106 \text { minutes }\end{array}$ \\
\hline Booth.50.7se (1999) & $\begin{array}{c}\text { DTB } \\
\text { Index options } \\
\text { From } 01 / 92 \text { to } 03 / 94\end{array}$ & Intraday quotes & Vur Enor correction model & $\begin{array}{l}\text { The cash market lend the options } \\
\text { market }\end{array}$ \\
\hline $\begin{array}{l}\text { Capelle-Bluncurd-Vundelanoite } \\
\qquad(2002)\end{array}$ & $\begin{array}{c}\text { MONEP } \\
\text { Index options } \\
\text { From } 01 / 97 \text { to } 12 / 99\end{array}$ & Intraday transactions & $\begin{array}{l}\text { Granger linear causality } \\
\text { Grunger non lineur cussality }\end{array}$ & $\begin{array}{c}\text { The cash market lend the options } \\
\text { market }\end{array}$ \\
\hline Easley -0'Hura-Srinivas (1998) & $\begin{array}{c}\text { CBOE } \\
\text { Stock options } \\
\text { From } 10,90 \text { to } 11 / 90\end{array}$ & $\begin{array}{l}\text { Intraday transaction } \\
\text { volumes }\end{array}$ & $\begin{array}{l}\text { Bivariute ARIMA } \\
\text { Linear cuusality }\end{array}$ & $\begin{array}{l}\text { Options murket is a venue for } \\
\text { information based trading }\end{array}$ \\
\hline Chan-Chung-fong (2002) & $\begin{array}{c}\text { CBOE } \\
\text { Stock options } \\
\text { From 01/95 to 03/95 }\end{array}$ & $\begin{array}{l}\text { Intraday transaction } \\
\text { volumes/ } \\
\text { initraday quotes }\end{array}$ & Test VAR und Granger & $\begin{array}{l}\text { Stock wolumes lead option } \\
\text { returns } \\
\text { Option volumes have no } \\
\text { predictive content for stock } \\
\text { prices }\end{array}$ \\
\hline
\end{tabular}




\begin{tabular}{|c|c|c|c|c|}
\hline Pan-Poteshman (2006) & $\begin{array}{c}\text { CBOE } \\
\text { Stock options/ndex options }\end{array}$ & Duily volumes & $\begin{array}{l}\text { Cross-yectional unalyses } \\
\text { (univuriatebrvariate regressions) }\end{array}$ & $\begin{array}{l}\text { Options market leads stock } \\
\text { murket }\end{array}$ \\
\hline & From $01 / 90$ to 30/2004 & & & $\begin{array}{l}\text { Index option buve no prodictive } \\
\text { content }\end{array}$ \\
\hline Cuo-Chen-Girffin (2005) & $\begin{array}{c}\text { CBOE } \\
\text { Stock options } \\
78 \text { events between } 1986 \text { and } 1994\end{array}$ & Iniraday transiction wolumes & $\begin{array}{c}\text { ARIMA } \\
\text { Lineur cuusality }\end{array}$ & $\begin{array}{l}\text { Option market plays an importan } \\
\text { role in information revelation } \\
\text { during pre-announcement penod }\end{array}$ \\
\hline caul-Nimaldran-Zhang (2004) & $\begin{array}{c}\text { CBOE } \\
\text { Stock options } \\
02295\end{array}$ & Intraday trade and quotes data & $\begin{array}{l}\text { Develop und test a model of } \\
\text { option spread OLS regression } \\
\text { und ordered Probit models }\end{array}$ & $\begin{array}{c}\text { Presence of strutegie trading by } \\
\text { informed investors in the options } \\
\text { murket }\end{array}$ \\
\hline $\begin{array}{l}\text { Chakravarty-(iulen-Mayhew } \\
\qquad(2004)\end{array}$ & $\begin{array}{c}\text { CBOE } \\
\text { Stock options }\end{array}$ & Intraday trade and quotes data & Contegration vector & $\begin{array}{l}\text { An important informational role } \\
\text { for options }\end{array}$ \\
\hline & From 1988 to 1992 & & & \\
\hline
\end{tabular}




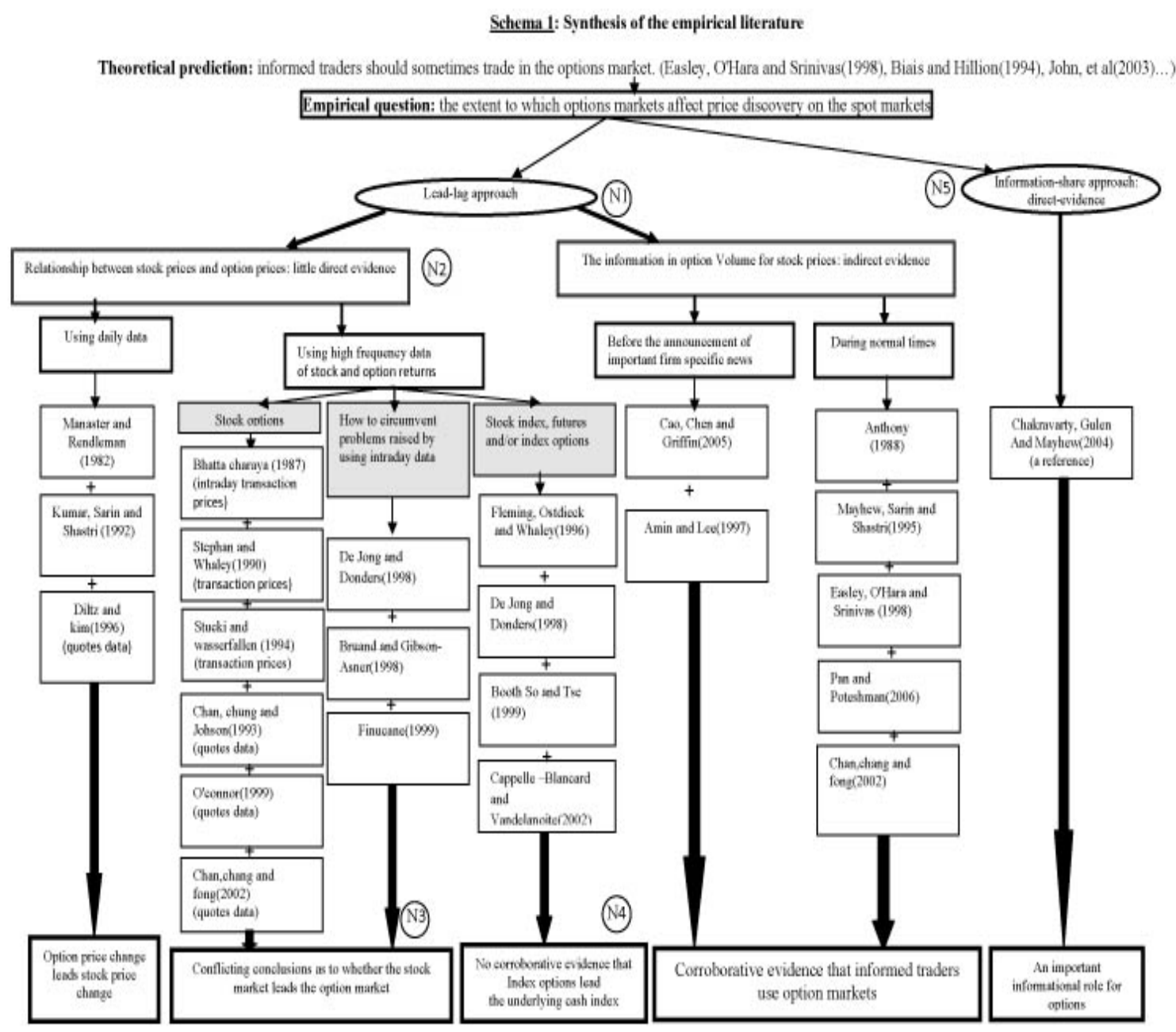

\section{Schema 1 notes}

N1: There is a substantial body of empirical research focusing on which market leads (or lags) in term of information arrival, through Granger lead-lag regressions and similar techniques.

N2: There is surprisingly little evidence that new information is reflected in option prices before stock prices.

N3: While these studies come to conflicting conclusions as to whether the stock market leads the option market, they consistently find no significant lead for the options market. This conclusion applies to the individual stock market, not the index options market where the underlying is not a traded asset.

N4: The authors have reported that the underlying index is not a traded asset. Thus, it may be composed of stale prices.

N5: The information-share approach measures the contribution of the innovation in the price process in one market (say the option market) to the total variance of the innovation in the permanent component of the price vector spanning both (stock and option) markets. 